\title{
SR proteins can compensate for the loss of U1 snRNP functions in vitro
}

\author{
Woan-Yuh Tarn and Joan A. Steitz ${ }^{1}$ \\ Department of Molecular Biophysics and Biochemistry, Howard Hughes Medical Institute, Yale University School \\ of Medicine, New Haven, Connecticut USA
}

\begin{abstract}
SR proteins are essential splicing factors that also influence $5^{\prime}$ splice site choice. We show that addition of excess mixed SR proteins to a HeLa in vitro splicing system stimulates utilization of a novel $5^{\prime}$ splice site (site 125) within the intron of the standard adenovirus pre-mRNA substrate. When U1 snRNPs are debilitated by sequestering the $5^{\prime}$ end of U1 snRNA with a $2^{\prime}-O$-methyl oligoribonucleotide, excess SR proteins not only rescue splicing at the normal site and site 125 but also activate yet another $5^{\prime}$ splice site (site 47 ) in the adenovirus intron. One SR protein, SC35, is sufficient to exhibit the above activities. The possibility that excess SR proteins recruit residual unblocked U1 snRNPs to participate in $5^{\prime}$ splice site recognition has been ruled out by psoralen cross-linking studies, which demonstrate that the $2^{\prime}$ - $O$-methyl oligoribonucleotide effectively blocks $5^{\prime}$ splice site/U1 interaction. Native gel analysis reveals a nearly normal splicing complex profile in the $2^{\prime}$-O-methyl oligoribonucleotide pretreated, SR protein-supplemented extract. These results indicate that SR proteins can replace some functions of the U1 snRNP but underscore the contribution of U1 to the fidelity of $5^{\prime}$ splice site selection.
\end{abstract}

[Key Words: SR proteins; Ul snRNPs; pre-mRNA splicing; 5' splice site selection]

Received July 28, 1994; revised version accepted September 29, 1994.

The splicing of pre-mRNA to produce functional message is a key step in gene expression. Most mammalian pre-mRNAs contain several introns, and some are alternatively spliced; therefore, the selection of splice sites must be highly accurate (for review, see Horowitz and Krainer 1993|. Splicing of pre-mRNA occurs in the spliceosome, a complex ribonucleoprotein particle composed of five small nuclear RNAs (snRNAs) (U1, U2, U4, U5, and U6) and numerous protein factors (for review, see Moore et al. 1993). Splicing proceeds through two sequential transesterification reactions. In the first step, the phosphodiester bond at the $5^{\prime}$ splice site is cleaved by nucleophilic attack of the 2 '-hydroxyl group of an adenosine located near the $3^{\prime}$ end of the intron. In the second step, the two exons are ligated with release of the intron lariat.

Complementarity between the $5^{\prime}$ splice site and the $5^{\prime}$ end of Ul snRNA is a major determinant in identification of the $5^{\prime}$ splice site, but base-pairing with U1 alone is not sufficient to specify the site of nucleophilic attack (Zhuang and Weiner 1986; Seraphin et al. 1988; Siliciano and Guthrie 1988; Seraphin and Rosbash 1990). Two other small nuclear ribonucleoproteins (snRNPs), U5 and U6, are known to contribute to $5^{\prime}$ splice site choice. Genetic experiments, initially performed in yeast, showed that mutations in the conserved first loop of U5 snRNA could activate aberrant $5^{\prime}$ splice sites after mu-

\footnotetext{
${ }^{1}$ Corresponding author.
}

tation of the normal $5^{\prime}$ splice site of the pre-mRNA (Newman and Norman 1991, 1992). Similar results were obtained in analogous experiments in the mammalian system (Cortes et al. 1993). Site-specific cross-linking studies further detected dynamic interactions between the conserved loop of U5 and exon sequences adjacent to both the $5^{\prime}$ and $3^{\prime}$ splice sites (Wyatt et al. 1992; Sontheimer and Steitz 1993). Together, these observations suggest that the U5 snRNP might influence $5^{\prime}$ splice site recognition by forming either Watson-Crick or noncanonical base-pairing interactions with the $5^{\prime}$ exon. Likewise, U6 has long been suspected to serve a vital role in the catalytic reactions of the spliceosome (for review, see Guthrie 1991). Cross-linking experiments in both mammalian and yeast systems first suggested interactions between intron sequences at the $5^{\prime}$ splice site and the invariant sequence ACAGAG in U6 snRNA /Sawa and Abelson 1992; Wassarman and Steitz 1992; Sontheimer and Steitz 1993). Genetic suppression data then showed that this U6 sequence can engage in Watson-Crick pairing with intron sequences and influence selection of the precise $5^{\prime}$ splice site (Kandels-Lewis and Seraphin 1993; Lesser and Guthrie 1993). However, the above examples of a dominant role for U5 or U6 in determination of the 5 ' cleavage site represent special circumstances, occurring only when the normal $5^{\prime}$ splice site has been mutated (Newman and Norman 1992; Kandels-Lewis and Seraphin 1993; Lesser and Guthrie 1993). Moreover, because the proposed pairings of the $5^{\prime}$ splice site to $U 1$ and 
U6 are mutually exclusive, these two interactions are believed to be sequential, with U6 making intron contacts only after U1 has left the 5' splice site (Konforti et al. 1993).

Yet other factors must therefore collaborate with U1 in the initial identification of the $5^{\prime}$ splice site during the commitment step in spliceosome assembly (for review, see Rosbash and Seraphin 1991; Manley 1993). Here, a family of proteins containing arginine/serine-rich (RS) domains has been implicated (for review, see Horowitz and Krainer 1993|. The so-called SR proteins include at least six related polypeptides that are conserved among metazoans (Roth et al. 1991; Zahler et al. 1992). SR proteins are essential for splicing and also influence the choice of $5^{\prime}$ splice site in alternatively spliced premRNAs (Ge and Manley 1990; Krainer et al. 1990a,b; Fu et al. 1992; Mayeda et al. 1992; Zahler et al. 1992). They commit a pre-mRNA to splicing (Fu 1993) and are required for A complex formation during spliceosome assembly (Fu and Maniatis 1990; Krainer et al. 1990a). Although the various SR proteins initially appeared to be functionally redundant, recent observations suggest differences in their ability to function as both essential and alternative splicing factors (Fu 1993; Zahler et al. 1993). With a precursor RNA containing multiple $5^{\prime}$ splice sites, high concentrations of SR proteins favor use of the proximal (downstream) $5^{\prime}$ splice site (Ge and Manley 1990; Krainer et al. 1990b; Fu et al. 1992; Zahler et al. 1993). The heterogeneous nuclear ribonucleoprotein A1 (hnRNP Al) has been shown to antagonize the activity of SR proteins in the selection of $5^{\prime}$ splice sites, suggesting that the relative concentrations of SR proteins and hnRNP Al in the cell may be critical (Mayeda and Krainer 1992; Yang et al. 1994).

The mechanism by which SR proteins contribute to spliceosome assembly and 5' splice site choice is only beginning to be elucidated. One SR protein, SC35, has been shown to mediate specific interactions between $\mathrm{Ul}$ and U2 snRNPs bound at the $5^{\prime}$ and $3^{\prime}$ splice sites, respectively, in the earliest ATP-dependent splicing complex (Fu and Maniatis 1992). Using a protein-protein interaction approach, Wu and Maniatis (1993) suggested further that SC35 and other SR proteins actually function as a bridge between the U1 snRNP-specific $70 \mathrm{~K}$ protein and the splicing factor U2AF bound to the $3^{\prime}$ splice site. Another SR protein, SF2/ASF, has been proposed to stabilize base-pairing of U1 snRNA to the pre-mRNA (Eperon et al. 1993). Recent studies show that this protein recognizes $5^{\prime}$ splice sites directly (Zuo and Manley 1994) and facilitates the binding of the Ul snRNP to the pre-mRNA by protein-protein interactions involving the RS domains of both ASF/SF2 and the U1-specific $70 \mathrm{~K}$ protein (Kohtz et al. 1994). In addition, SR proteins have been shown to bind exonic purine-rich sequences and enhance the utilization of upstream $3^{\prime}$ splice sites (Lavigueur et al. 1993; Sun et al. 1993; Tian and Maniatis 1993; Amrein et al. 1994).

We set out to ask whether SR proteins can promote the interaction between a $5^{\prime}$ splice site and the U6 snRNP, allowing $\mathrm{U} 6$ to replace $\mathrm{U} 1$ in interacting with the $5^{\prime}$ splice site during the conversion of early splicing complexes to the active spliceosome. SR proteins from HeLa cells were therefore added to a pre-mRNA splicing reaction in the presence or in the absence of functional U1 snRNPs. We discovered that excess amounts of SR proteins can activate a novel $5^{\prime}$ splice site within the intron of the standard splicing substrate derived from the adenovirus major late transcript (Solnick 1985). Furthermore, when the U1 snRNP was debilitated by stably sequestering its $5^{\prime}$ end with a $2^{\prime}$-O-methyl oligoribonucleotide (Seiwert and Steitz 1993), excess SR proteins rescued the splicing activity of the extract, activating yet another novel $5^{\prime}$ splice site within the intron. We conclude that $S R$ proteins can compensate for the requirement for the $5^{\prime}$ end of U1 snRNA in the splicing of premRNA but do not distinguish true from alternative $5^{\prime}$ splice sites. We discuss the relative roles of SR proteins, U1 and U6 snRNPs in 5' splice site selection, and spliceosome assembly.

\section{Results}

Excess SR proteins induce use of a novel 5' splice site within the intron of the adenovirus pre-mRNA substrate

Isolation of SR proteins from HeLa nuclear extracts was carried out by a two-step salt precipitation as described by Zahler et al. (1992). The SR protein preparation contained six primary polypeptides (data not shown), as reported (Zahler et al. 1992). The SR proteins were assayed for their ability to complement a HeLa S100 extract using two standard splicing substrates, derived from either the adenovirus major late or the human $\beta$-globin transcript. As shown in Figure 1A, the unsupplemented $\$ 100$ extract was unable to splice the pre-mRNA (lanes 2,6). However, S100 extract became splicing competent by complementation with mixed SR proteins (at approximately twofold the level in nuclear extract), exhibiting the same splicing pattern as the nuclear extract (lane 4, products marked and lane 8). Addition of excess SR proteins $(\sim 20$-fold the endogenous level) altered the pattern of splicing products from the adenovirus substrate substantially (lane 3 , products marked *), suggesting the activation of an alternative splice site. Titration of SR proteins while holding the amount of $S 100$ extract constant showed that the ratio of utilization of the alternative site relative to the normal site increased with increasing amounts of SR proteins (data not shown). Likewise, when nuclear extract was supplemented with additional SR proteins, the ratio of alternative to normal splicing of the adenovirus transcript increased in a concentration-dependent manner (data not shown). In contrast, the $\beta$-globin transcript showed stimulation, but an unchanged pattern of splicing products, in the presence of high concentrations of SR proteins (Fig. 1A, lane 7).

To determine the position of the novel adenovirus splice site activated by excess SR proteins, individual RNAs were gel purified from the splicing reaction and then incubated with the $\$ 100$ extract, which contains 
Figure 1. Alternative splicing of the adenovirus substrate induced by mixed SR proteins. (A) Splicing was carried out in HeLa nuclear extract (NE), or S100 extract (S100), or S100 extract complemented with different amounts of SR proteins using a pre-mRNA derived from the adenovirus major late transcript (Ade) or the $\beta$-globin pre-mRNA ( $\beta$-globin). Symbols at left indicate the adenovirus precursor, as well as the splicing intermediates and products using the normal $5^{\prime}$ splice site $(0)$ or an alternative $5^{\prime}$ splice site at position +125 within the intron $\left({ }^{*}\right)$. Symbols at right indicate the $\beta$-globin precursor RNA, splicing intermediates, and products. Marker shows ${ }^{32} \mathrm{P}$-labeled pBR322 DNA digested with MspI, with the fragment lengths in nucleotides given at left. The smear in lane 1 migrating below the excised intron lariat is polyadenylated substrate (data not shown). (B) The sequence at the splice junction of the alternatively spliced product (excised from a gel as in $A$, lane 3 ) was determined by dideoxy sequencing. The sequencing reaction, using oligonucleotide AdEII as primer, was carried out in the absence of dideoxynucleotide (lane 1) or in the presence of ddA (lane 2), ddT (lane 3), ddG (lane 4), or ddC (lane 5). The arrow denotes the splice junction. $(C)$ Sequences at the novel $5^{\prime}$ splice site $(+125)$ within the intron of the adenovirus transcript and the 3 ' splice site are shown with uppercase and lowercase letters representing exon and intron regions, respectively. The size of the normal intron is 241 nucleotides, whereas the intron removed by splicing at site +125 is 117 nucleotides.

debranching activity. Two molecules containing a branch / the lariat and lariat intermediate indicated by * in Fig. 1A, lane 3) were identified by their altered mobility on a denaturing gel (data not shown), and their $5^{\prime}$ ends were determined by primer extension. These analyses established the position of the novel $5^{\prime}$ splice site 125 nucleotides downstream of the normal site (data not shown). The sequences adjacent to the cleavage-ligation site were then determined by dideoxy sequencing of the spliced product (Fig. 1B) and revealed that the novel $5^{\prime}$ splice site within the intron becomes joined to the normal adenovirus $3^{\prime}$ splice site (Fig. 1C). It should be noted that the first intron of the adenovirus major late transcript has been shortened in our pre-mRNA construct (Solnick 1985); in an in vivo adenovirus transcript, a much longer sequence $(\sim 800$ nucleotides) intervenes between site 125 and the branch site.

\section{$S R$ proteins can activate yet another $5^{\prime}$ splice site (site 47) in the absence of functional U1 snRNA}

To ask whether SR proteins act autonomously in selecting the novel $5^{\prime}$ splice site at position 125 of the adenovirus intron, the splicing extract was pretreated with an antisense 2 '- $O$-methyl oligoribonucleotide $\left(\mathrm{Ul}_{1-14}\right) \mathrm{com}$ plementary to the sequence at the $5^{\prime}$ end of U1 snRNA. The $U 1_{1-14}$ oligonucleotide had been shown previously to effectively abolish splicing not only of the standard adenovirus pre-mRNA but also of spliced leader (SL) RNA-containing chimeric substrates; in contrast to shorter anti-U1 oligonucleotides, which do not block splicing of such chimeric transcripts, $\mathrm{Ul}_{1-14}$ interferes with an additional function of the U1 snRNP and prevents formation of stable complex A (Seiwert and Steitz 1993). Two other 2'-O-methyl oligoribonucleotides, U2b and $\mathrm{U} 7_{3-20}$, were used as controls. U2b is complementary to a region of $U 2$ that recognizes the branch site region of the intron and has been shown to block $\mathrm{A}$ complex formation completely (Lamond et al. 1989); U7 $7_{3-20}$ is complementary to a nonspliceosomal RNA.

Consistent with previous results, preincubation of nuclear extract with either the $\mathrm{U} 1_{1-14}$ or U2b oligonucleotide significantly blocked splicing activity (Fig. 2A, lanes 5,6$)$, whereas the $U 7_{3-20}$ oligonucleotide had no effect except for nonspecific increases in RNA stability and debranching activity (lane 7). Addition of a high level of mixed SR proteins to $\mathrm{S} 100$, mock-treated or $\mathrm{U}_{3-20^{-}}$ pretreated nuclear extract (lanes 3,8,11) induced selection of the alternative $5^{\prime}$ splice site, 125 nucleotides downstream of the normal site, as expected. Surprisingly, the extract pretreated with the $\mathrm{Ul}_{1-14}$ oligonucleotide also became splicing competent after supplementation with the same high amount of SR proteins (lane 9), suggesting that SR proteins can somehow substitute for the U1 snRNP functions blocked by this oligonucleotide. The same extract pretreated with the U2b oligo- 

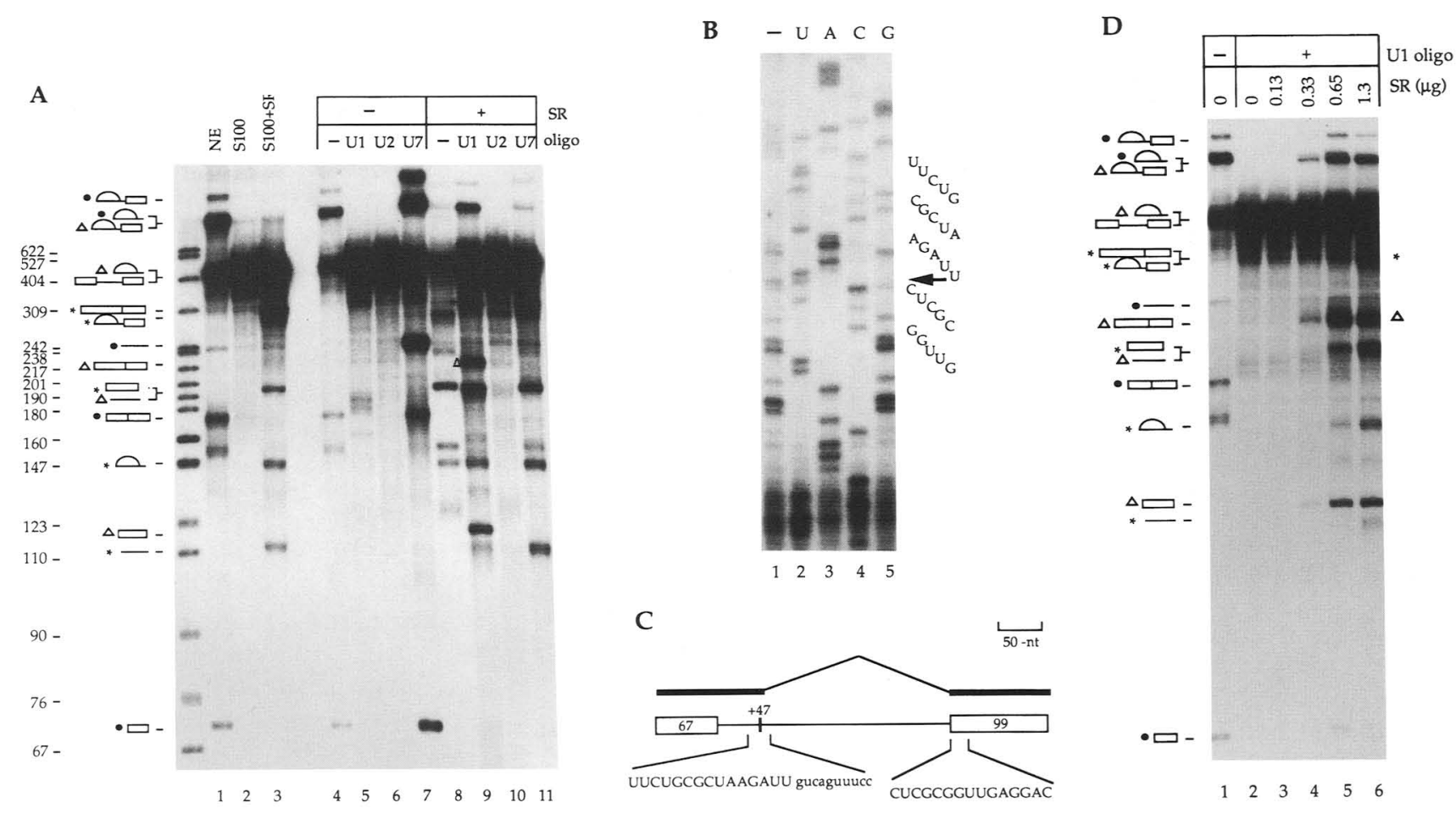

Figure 2. SR proteins rescue splicing and activate a second novel $5^{\prime}$ splice site $(+47)$ within the intron of the adenovirus substrate when the $5^{\prime}$ end of U1 snRNA is sequestered by an antisense $2^{\prime}$-O-methyl oligoribonucleotide. (A) Lanes $1-3$ show 10- $\mu l$ splicing reactions carried out with HeLa nuclear extract (NE), S100 extract (S100), or S100 extract supplemented with $1.5 \mu \mathrm{g}$ of mixed SR proteins. For lanes 4-11, nuclear extracts were preincubated under splicing conditions for 10 min in the absence of oligonucleotide (lanes 4,8 ) or in the presence of $2^{\prime}$-O-methyl oligoribonucleotide $U 1_{1-14}$ (lanes 5,9), U2b (lanes 6,10) or U7 $3-20$ (lanes 7,11). Then, labeled adenovirus substrate, along with $5 \%$ glycerol-containing buffer D (lanes 4-7) or micrococcal nuclease-treated SR proteins (1.5 $\mu$ g) (lanes 8-11), were added and incubation continued for $90 \mathrm{~min}$. Symbols at left indicate the precursor RNA, as well as the splicing intermediates and products using the normal $5^{\prime}$ splice site $(O)$, using site $125\left(^{\star}\right)$ or using site $47(\Delta)$. Size markers are as in Fig. $1 \mathrm{~A}$. Note that the spliced product of site 125 reproducibly migrates slightly fast in lane 8 but behaves normally in both lanes 9 and 11 . When lane 8 was examined at earlier times, this band migrated normally after 30 min of incubation and smeared slightly at 60 min; when the extract was supplemented with SR proteins that were not treated with micrococcal nuclease, its mobility was normal. Thus, it appears that some micrococcal nuclease activity remains in mock-treated extracts, which can be competed by oligoribonucleotides and prevents digestion of the RNA in lanes 9 and 11. The comigration of the debranched lariat from site 47 with excised exon from site 125 was established by primer extension analysis. $(B)$ The sequence at the splice junction of the site 47 spliced product (excised from a gel as in $A$, lane 9| was determined by dideoxy sequencing. The sequencing reaction, using oligonucleotide AdEII as primer, was carried out in the absence of dideoxynucleotide (lane 1), or in the presence of ddA (lane 2), ddT (lane 3), ddG (lane 4), or ddC (lane 5). The arrow denotes the splice junction. (C) Sequences at site 47 within the intron of the adenovirus transcript and at the 3 ' splice site are presented, with uppercase and lowercase letters representing exon and intron regions, respectively. The size of the intron removed by splicing at site +47 is 195 nucleotides. $(D)$ Lane 1 shows a 10- $\mu$ l splicing reaction performed with normal nuclear extract. For lanes $2-6$, the nuclear extract was pretreated with the $2^{\prime}-O$-methyl oligoribonucleotide $U 1_{1-14}$ as in $A$, lanes 5 and 9 . Then, labeled adenovirus substrate, along with $5 \%$ glycerol-containing buffer D (lane 2) or increasing amounts of micrococcal nuclease-treated SR proteins, was added (lanes 3-6), and incubation continued for $90 \mathrm{~min}$. Gel fractionation and symbols are as in $A$.

nucleotide was unable to be activated by SR proteins (lane 10). Analogous experiments performed in S100 extracts (not shown) yielded the same results.

Because SR proteins prepared by salt precipitation contain trace amounts of U1 snRNA $\{1$ 14-20 fmoles of U1 snRNA per microgram of SR proteins; data not shown), we pretreated the preparation extensively with micrococcal nuclease. In Northern blot analyses, the amount of $\mathrm{Ul}$ was reduced to undetectable levels /data not shown). Yet, the ability of the treated SR protein preparation to activate splicing even when the $5^{\prime}$ end of U1 was blocked was no different from untreated SR proteins (data not shown). Therefore, micrococcal nucleasetreated SR protein preparations were used in Figure 2 and in further experiments. The possible involvement of residual U1 snRNPs in complemented splicing reactions is addressed below.

When the $U 1_{1-14}$ oligonucleotide-pretreated extract was supplemented with excess SR proteins, not only did splicing occur at both the normal and +125 sites, but at least one more splice site was activated (Fig. 2A, lane 9). As described above, each RNA species was excised from the gel and subjected to the debranching assay. In addition to those bands characterized in Fig. 1 /corresponding 
to use of the +125 sitel, two new prominent species were sensitive to the debranching activity (data not shown). The $5^{\prime}$ ends of these RNAs were determined by primer extension, revealing yet another 5 ' splice site located 47 nucleotides downstream of the normal site (data not shown). Again, the exon sequences flanking the splice junction were confirmed by dideoxy sequencing of the spliced product (Fig. 2B), demonstrating that site 47 also becomes joined to the normal adenovirus 3 ' splice site (Fig. 2C). The intermediates and products associated with splicing at position 47 are indicated $(\Delta)$ in Figure $2 A$.

We showed above that titration of SR proteins into S100 (Fig. 1) or nuclear extracts (both of which have functional U1 snRNPs) causes a concentration-dependent switch from use of the normal to the alternative (site 125) 5 ' splice site. When the $\mathrm{Ul}_{1-14}$ oligonucleotide-pretreated extract was likewise supplemented with various amounts of SR proteins, optimal splicing /more than severalfold the level in normal extracts/ was obtained at 10-fold the endogenous level of SR proteins (Fig. 2D, lane 5). At this SR protein concentration, use of the normal $(+1) 5^{\prime}$ splice site began to approach that in normal extracts (cf. $O$ in lane 5 with lane 1). Increasing the amount of SR proteins further (to 20-fold) resulted in a decrease in splicing at the normal $5^{\prime}$ splice site relative to the alternative site 125 , but little change was found in use of site 47, which predominates (cf. lanes 5 and 6). Quantitation of the efficiency of splicing to each of the three $5^{\prime}$ splice sites (for details, see Fig. 6 legend) under such conditions is presented in Figure 6.

Finally, we used an alternative method to inactivate the U1 snRNP and assessed the effect of excess SR proteins. Previous reports established that the splicing of the adenovirus substrate is almost completely abolished when the $5^{\prime}$ end of U1 snRNA is destroyed by RNase $\mathrm{H}$ digestion in the presence of the $\mathrm{Ul}_{1-12}$ deoxyoligonucleotide (see Seiwert and Steitz 1993 and references therein). After such pretreatment of the extract, we observed that excess SR proteins were able to restore the splicing efficiency as well as activate three $5^{\prime}$ splice sites concomitantly (data not shown).

In summary, our results indicate that excess mixed SR proteins stimulate utilization of a novel $5^{\prime}$ splice site at position 125 of the adenovirus intron in S100 and nuclear extracts, whereas the additional presence of the $\mathrm{Ul}_{1-14}$ oligonucleotide leads to concomitant use of three 5 ' splice sites. Site 47 is silent in the presence of functional Ul snRNA but is selected predominantly when the $5^{\prime}$ end of U1 snRNA is sequestered. Moreover, when a titration of the $\mathrm{Ul}_{1-14}$ oligonucleotide $(1.5-15 \mathrm{mM})$ was performed, we found that the efficiency of splicing at site 47 increased with increasing amounts of the oligonucleotide in the SR protein-supplemented extract, confirming a direct correlation between activation of site 47 and inactivation of Ul snRNA (data not shown). Because excess SR proteins can efficiently (but with reduced fidelity) rescue the splicing defect of an extract in which the $5^{\prime}$ end of U1 snRNA is masked by an antisense oligonucleotide, it appears that SR proteins can substitute at least partially for functions of the Ul snRNP.

\section{SC35 alone can rescue splicing when the $5^{\prime}$ end of U1 snRNA is sequestered}

Different SR proteins have distinguishable characteristics (Fu 1993; Sun et al. 1993; Zahler et al. 1993), raising the question of which is contributing to the splicing we observe in the presence of debilitated U1 snRNPs. SC35 purified from the baculovirus expression system (the kind gift of M. Tian and T. Maniatis, Harvard University, Cambridge, $\mathrm{MA} /$ was added to a $\mathrm{Ul}_{1-14}$ oligonucleotidepretreated extract. Figure 3, lane 6, shows that SC35 alone can rescue the splicing activity of such an extract and mediate utilization of the same three $5^{\prime}$ splice sites as a comparable amount of mixed SR proteins. Because only limited amounts of purified SC35 were available, we altered the assay conditions in Figure 3 to use $40 \%$ rather than $60 \%$ extract (see Materials and methods). Although the same amount of SR proteins as in Figure $2 \mathrm{~A}$ was supplied, splicing to site 125 was preferred over site 47 (by $\sim 1.5$-fold) instead of the reverse (cf. Fig. 3, lane 4, with Fig. 2A, lane 91. This suggests that some extract factor that exhibits a preference for site 47 may collaborate with SR proteins in the selection of $5^{\prime}$ splice sites in the absence of Ul snRNPs. Again, the splicing activity of the $\mathrm{U} 2 \mathrm{~b}$ oligonucleotide-pretreated extract

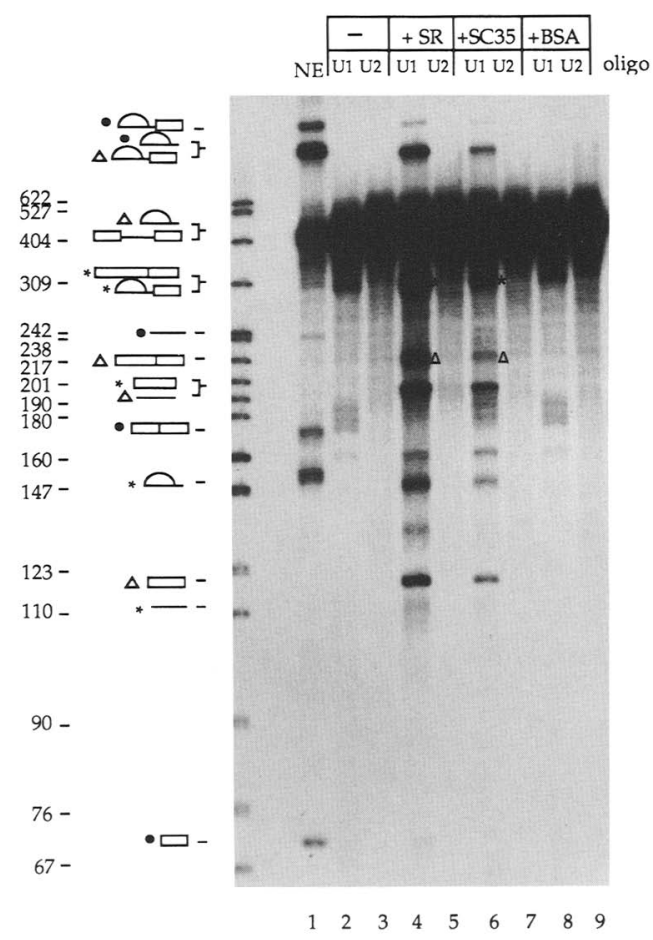

Figure 3. SC35 can rescue splicing and activate site 47 in the absence of functional U1 snRNA. Nuclear extracts were pretreated in bulk with 2 '-O-methyl oligoribonucleotide $\mathrm{Ul}_{1-14}$ (lanes $2,4,6,8$ ) or $U 2 b$ (lanes $3,5,7,9$ ) under splicing conditions for $10 \mathrm{~min}$. After addition of ${ }^{32} \mathrm{P}$-labeled adenovirus substrate along with $5 \%$ glycerol-containing buffer D (lanes 2,3), $1.5 \mu \mathrm{g}$ of mixed SR proteins (lanes 4,5), $1.6 \mu \mathrm{g}$ of purified SC35 (lanes 6,7 ), or $1.6 \mu \mathrm{g}$ of BSA (lanes 8,9 ), incubation was continued for 90 min. Lane 1 shows splicing in an untreated nuclear extract. Size markers and symbols are as in Fig. 2A. 
was not able to be rescued either by mixed SR proteins or by SC35 (Fig. 3, lanes 5,7). Likewise, BSA did not restore the splicing activity of oligonucleotide-pretreated extracts (lanes 8,9).

In addition to the standard adenovirus pre-mRNA, we examined a chimeric substrate (C/Ad) (Bruzik and Steitz 1990), which contains an SL RNA 5' splice site and lacks adenovirus sites 47 and 125 , to ask whether the ability of mixed SR proteins or SC35 to compensate for functions of the U1 snRNP is general. Splicing of the C/Ad construct was shown previously to be blocked completely by preincubation with the $\mathrm{Ul}_{1-14}$ oligonucleotide (Seiwert and Steitz 1993). We observed that this block can be rescued fully by supplementation with either mixed SR proteins or SC35 alone (data not shown). Thus, mixed SR proteins or SC35 alone can commit even a variant $5^{\prime}$ splice site to splicing in the presence of debilitated $\mathrm{U} 1$ snRNPs. Moreover, the splicing of C/Ad occurred only at the authentic $5^{\prime}$ splice site in the absence of competitive sites, indicating that reconstitution by SR proteins is not limited to certain special downstream sites.

\section{Psoralen cross-linking of U1 snRNA to $5^{\prime}$ splice sites is effectively blocked by the $U 1_{1-14}$ oligonucleotide in $S R$ protein-supplemented extract}

There are several possible explanations for the observation that SR proteins can rescue the splicing activity of an extract in which the $5^{\prime}$ end of U1 RNA is blocked by an antisense $2^{\prime}$-O-methyl oligoribonucleotide. It could be that an RNA unwinding activity induced by addition of SR proteins disrupts the U1 snRNA-antisense oligonucleotide duplex, reactivating U1 to perform its normal role in splicing. Alternatively, a tiny fraction of the U1 snRNPs in the extract could remain free and be actively recruited to potential $5^{\prime}$ splice sites by excess SR proteins; in our standard splicing assay, there is an $\sim 1000$ fold excess of U1 snRNP over substrate. Finally, SR proteins may be capable of substituting for those U1 snRNP functions blocked by the oligonucleotide. We employed psoralen cross-linking (Wassarman and Steitz 1992, Seiwert and Steitz 1993) to differentiate among these possibilities.

Because splicing in the presence of the $\mathrm{Ul}_{1-14}$ oligonucleotide and excess SR proteins is highly efficient (Figs. 2A and 3), cross-linking to the pre-mRNA should not be diminished if U1 snRNPs are being either reactivated or recruited from a small residual pool. The adenovirus substrate was incubated under splicing conditions for $10 \mathrm{~min}$ and then irradiated on ice with $365-\mathrm{nm}$ light in the presence of AMT psoralen. No specific crosslinked products were observed in the absence of nuclear extract (Fig. 4A, lane 2), whereas U1 cross-linking to the normal 5' splice site (U1 $\times 1$; see below) was seen in both the nuclear extract and the SR protein-supplemented extract (lanes 3,5). At high concentrations of SR proteins, formation of the $U 1 \times 1$ cross-linked product was enhanced to more than three-fold that in the unsupplemented extract (lane 5), and two new closely migrating bands corresponding to U1 cross-linking to site 125
$(\mathrm{U} 1 \times 125$; see below) appeared. The species labeled $\mathrm{U} 1 \times 1$ and $\mathrm{U} 1 \times 125$ were determined to contain $\mathrm{U} 1 \mathrm{sn}-$ RNA by oligonucleotide-directed RNase $H$ cleavage both were cleaved with an oligonucleotide complementary to Ul snRNA, $\mathrm{Ul}_{64-75}$ (lanes 4,6 ). These data demonstrate that both $5^{\prime}$ splice sites are occupied by $\mathrm{U} 1$ snRNPs even though high concentrations of SR proteins lead to preferred use of the downstream site (site 125). Note that because the efficiency of cross-linking depends on the geometry (sequence) of the reactive sites, relative cross-linking is not a measure of the relative occupancy of the two sites by the U1 snRNP.

In the nuclear extract pretreated with the 2'-O-methyl oligonucleotide $\mathrm{U} 1_{1-14}$ (Fig. 4A, lanes 7,8), the U1-specific cross-linked products disappeared, as expected. Titrations of the oligonucleotide moreover revealed a direct correlation between splicing and cross-linking at sites +1 and +125 (data not shown). Significantly, when splicing was restored to the $\mathrm{Ul}_{1-14}$ oligonucleotide-pretreated extract by complementing with SR proteins, the cross-linked products containing Ul snRNA did not reappear (lanes 9,10), although cross-linked products with U2 were formed (see below). Likewise, in the absence of ATP, conditions favoring only formation of the earliest pre-splicing complex (E complex) (Michaud and Reed 1991), no cross-linked products were detected in the $\mathrm{U} 1_{1-14}$-pretreated and SR protein-supplemented extract, whereas in a normal extract lacking ATP, U1 cross-linking to site +1 was enhanced (data not shown). These results argue that the $5^{\prime}$ end of U1 snRNA does not participate in the splicing events activated by excess SR proteins in the presence of the $\mathrm{U}_{1-14}$ oligonucleotide. We can rule out the possibility that excess SR proteins block the access of psoralen because U1-substrate crosslinking is stimulated by SR proteins in the presence of functional U1 snRNPs (lane 5 vs. lane 3).

To locate the sites of cross-linking precisely on the adenovirus substrate and U1 RNA, we performed primer extension analyses on gel-purified cross-linked RNAs. Reverse transcription from a primer complementary to a region $3^{\prime}$ of a cross-linked site will terminate at the residue preceding a psoralen cross-linked nucleotide (Piette and Hearst 1983). Analysis of cross-linked RNA U1 $1 \times 1$ using an antisense adenovirus sequence as primer mapped blockage primarily to nucleotide $\mathrm{U}^{+9}$ (the ninth nucleotide of the intron) but also to $\mathrm{C}^{+8}$ (Fig. 4B). Previously, the second nucleotide of $U 1$ snRNA $\left(U^{2}\right)$ had been identified as cross-linking to nucleotides $\mathrm{C}^{+8}$ and $\mathrm{U}^{+9}$ of the adenovirus intron under normal splicing conditions (Wassarman and Steitz 1992). The two U1 $\times 125$ cross-linked bands were analyzed separately; both showed stops prior to nucleotide $\mathrm{U}^{+123}$ and nucleotide $\mathrm{U}^{+147}$ of the intron (Fig. $4 \mathrm{C}$; data not shown). It is unclear why the $\mathrm{U} 1 \times 125$ band is a doublet; however, we determined that the stop at nucleotide $\mathrm{U}^{+147}$ probably results from intramolecular cross-linking or a psoralen monoadduct because primer extension on precursor RNA cross-linked in the absence of extract yielded this product (data not shown). To determine which nucleotide of U1 snRNA becomes cross-linked to residue 

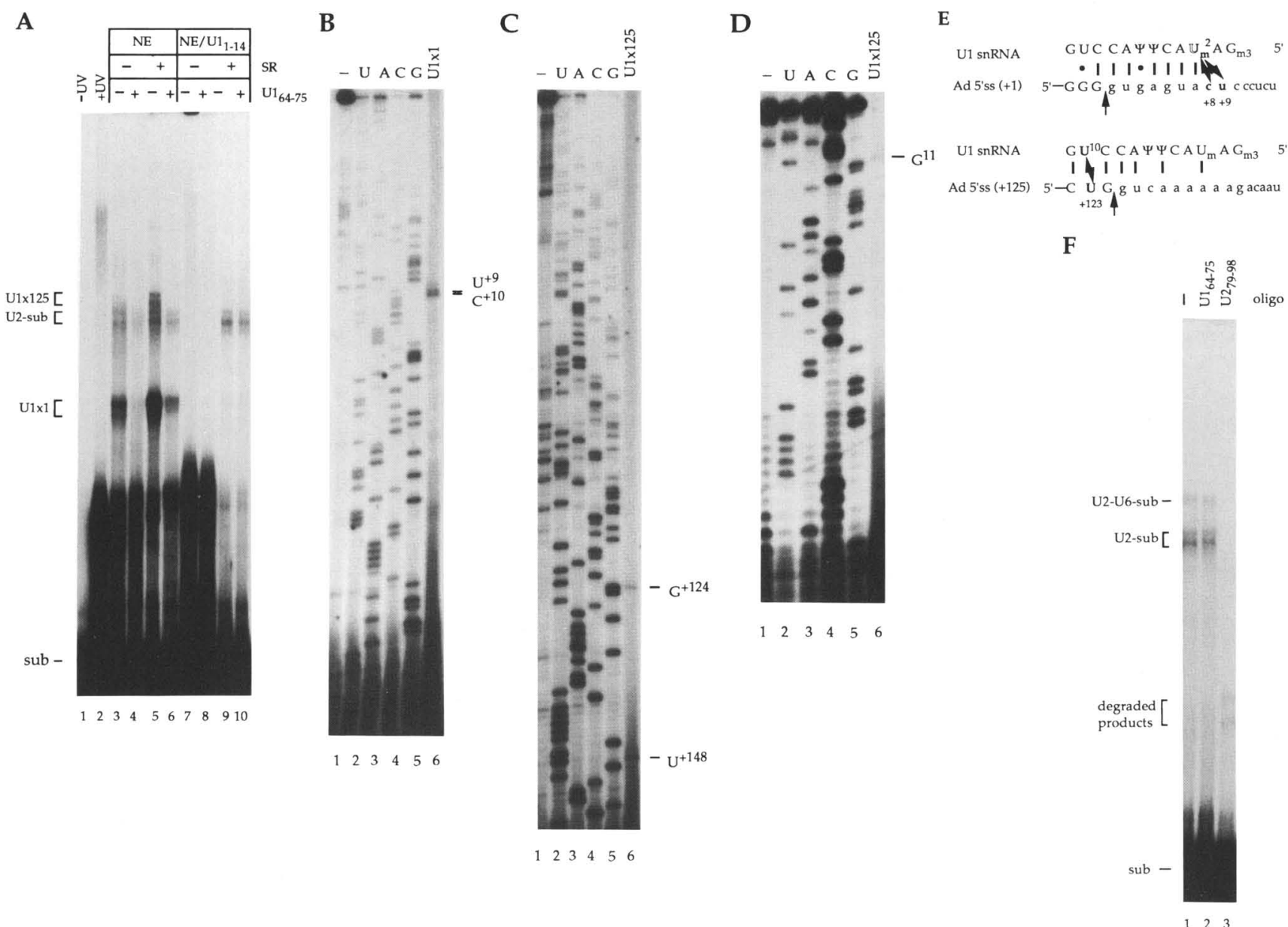

Figure 4. Evidence that the $5^{\prime}$ end of U1 snRNA is not involved in $5^{\prime}$ splice site recognition in the $\mathrm{U} 1_{1-14}$ oligonucleotide-pretreated and SR protein-supplemented extract. (A) Splicing reactions were performed for $10 \mathrm{~min}$ in mock-treated nuclear extract (lanes 3,4), mock-treated and SR protein-supplemented extract (lanes 5,6), U1 $1_{1-14}$ oligonucleotide-pretreated extract (lanes 7,8), or U1 $1-14$ oligonucleotide-pretreated and SR protein-supplemented extract (lanes 9,10). AMT psoralen was added to the reaction mixtures and irradiation with 365-nm light was carried out. RNAs recovered from each reaction were aliquoted into two fractions, followed by addition of RNase $\mathrm{H}$ alone (lanes 3,5,7,9) or RNase $\mathrm{H}$ plus $1 \mu \mathrm{g}$ of $\mathrm{Ul}_{64-75}$ (lanes $4,6,8,10$ ). The identities of the cross-linked species, as determined below, are indicated at left. (Lanes 1,2) Precursor RNA that was not or was irradiated with 365-nm light in the presence of AMT psoralen, respectively. Quantitation indicated that $\sim 15 \%$ of the $\mathrm{U} 1 \times 1$ bands remained undigested by RNase $\mathrm{H}$ in both lanes 4 and $6 ;<1.5 \%$ residual U $1 \times 125$ and U $1 \times 1$ cross-linking was detected in the U1-blocked extracts (cf. lane 9 to lane 5). (B) The cross-linked U $1 \times 1$ RNA was gel-purified from a reaction containing excess SR proteins, as in lane 5 of $A$, and the cross-linked site mapped on the precursor RNA by primer extension using oligonucleotide Adla as primer (lane 6). Dideoxy sequencing reactions using the same primer included no dideoxynucleotide (lane 1), ddA (lane 2), ddT (lane 3), ddG (lane 4), or ddC (lane 5). Although stops at $\mathrm{C}^{+10}$ and $U^{+9}$ are clearest, the faint stop at $A^{+7}$ may indicate weak cross-linking to $U^{+6}$, as well. (C) The cross-linked site of the $U 1 \times 125$ species was mapped similarly on the precursor RNA by primer extension using oligonucleotide AdIb as primer (lane 6$)$. $(D)$ The cross-linked site of $U 1 \times 125$ was mapped on U1 snRNA, using oligonucleotide $U 1_{64-75}$ as primer (lane 6) and gel-purified U1 snRNA as the template in lanes $1-5$. (E) Complementarity between the adenovirus $5^{\prime}$ splice sites $(+1$ or +125$)$ and U1 snRNA is indicated by thick vertical lines for Watson-Crick base pairs or dots for G-U. The cross-linked nucleotides identified here are indicated in bold, with that determined previously by Wassarman and Steitz (1992) in outline. The cross-linked nucleotides are indicated by a lightning bolt. The $5^{\prime}$ splice site is marked by an arrow. $(F)$ Cross-linked RNA was isolated from a reaction as in lanes 9 and 10 of $A$. Oligonucleotide-directed RNase $H$ cleavage was performed in the absence of oligonucleotide (lane 1 ) or in the presence of U1 $1_{64-75}$ (lane 2) or U2 ${ }_{79-98}$ (lane 3). Note that the higher yield of U2-U6-substrate cross-link in $F$ compared with $A$ is attributable to a different extract.

$\mathrm{U}^{+123}$, we also performed primer extension analysis on the U1 $\times 125$ bands with an oligonucleotide complementary to U1 snRNA. As illustrated in Figure 4D, the crosslink mapped to nucleotide $U^{10}$ of U1 snRNA, show- ing that base-pairing with U1 snRNA occurs when usage of site 125 is induced by excess SR proteins (and the $5^{\prime}$ end of $\mathrm{U} 1$ is not blocked). Primer extension analysis performed on $\mathrm{U} 1 \times 1$ - or $\mathrm{U} 1 \times 125$-comigrating RNA isolated 
from a cross-linking reaction in the absence of the splicing substrate showed no specific stops (data not shown). Deduced base-pairing interactions adjacent to crosslinked nucleotides in Ul snRNA and the normal 5' splice site, as well as in the downstream site (site 125), are shown in Figure 4E.

Finally, we identified other snRNAs that became cross-linked to the pre-mRNA in reactions performed in the presence of the $\mathrm{Ul}_{1-14}$ oligonucleotide and excess SR proteins. RNase $\mathrm{H}$ cleavage experiments were conducted using oligonucleotides complementary to U1 or U2 (Fig. 4F) and to U4, U5, or U6 (data not shown). The bands targeted in the presence of the U2 oligonucleotide correspond to U2-substrate and U2-U6-substrate cross-linked products, both identified previously (Wassarman and Steitz 1992). None of the cross-linked species obtained at this early time in the splicing reaction $(10 \mathrm{~min})$ were found to contain U4 or U5 snRNAs. These results suggest that the U2 snRNP contributes to splicing in the U1-blocked, SR protein-supplemented extract as in a normal reaction.

Splicing complexes in the $U 1_{1-14}$ oligonucleotidepretreated extract rescued by SR proteins

Seiwert and Steitz (1993) showed that formation of presplicing complex A is slowed significantly in extracts pretreated with the $\mathrm{U}_{1-14} 2^{\prime}$-O-methyl oligonucleotide, whereas the appearance of later complexes $B$ and $C$ is almost completely abolished. We therefore examined the assembly of splicing complexes when SR proteins rescue splicing in extracts blocked with the $\mathrm{U} 1_{1-14}$ oligonucleotide. Consistent with previous results (Seiwert and Steitz 1993), only a trace amount of complex A was formed in the $U 1_{1-14}$ oligonucleotide-pretreated extract (Fig. 5, lanes 7-9). In contrast, a profile showing splicing complexes A, B (which migrates slightly faster than normall, and $C$ was restored by addition of excess SR proteins (lanes 10-12). However, constant levels of complex $A$ and a novel complex (marked *) were observed at all time points, whereas both complexes A and B peak early and then diminish in the mock-treated and SR proteinsupplemented extract (lanes 4-6) or in a U7 $3-20$-pretreated and SR protein-supplemented extract /data not shown). Preliminary studies of the accumulated complex $A$ and the new complex showed that they both contain $\mathrm{U} 2$, but not U6, and that their assembly requires ATP and $30^{\circ} \mathrm{C}$ incubation. The buildup of complex A may be explained if association of $\mathrm{U} 6$ with the $5^{\prime}$ splice site in the absence of functional U1 becomes rate-limiting, causing the accumulation of a previous splicing complex. The kinetics of splicing (data not shown) and the formation and snRNP constituents of complex $\mathrm{C}$ do not differ significantly in mock-treated extract or in SR protein-supplemented extracts with or without $\mathrm{U1} 1_{1-14}$ (Fig. 5, lanes 1-6, 10-12; data not shown|. These results suggest that SR proteins facilitate the formation of early splicing complexes, whether or not the Ul snRNP is fully functional. Even excess SR proteins do not appear

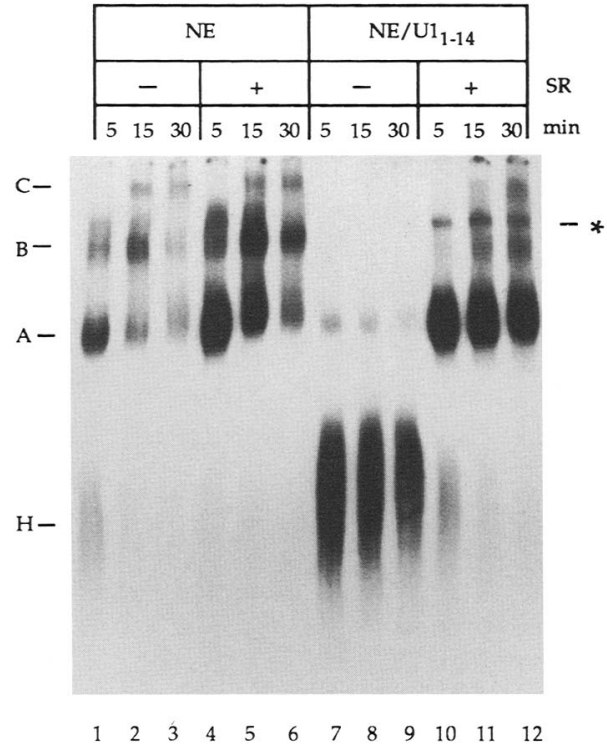

Figure 5. Native gel electrophoresis of splicing complexes formed in SR protein-rescued extracts. Splicing reactions were carried out in mock-treated extract (lanes 1-3), mock-treated, SR protein-supplemented extract (at $0.15 \mu \mathrm{g} / \mu \mathrm{l}$ ) (lanes 4-6), $\mathrm{U} 1_{1-14}$ oligonucleotide-pretreated extract (lanes $7-9$ ) or $\mathrm{U} 1_{1-14}$ oligonucleotide-pretreated, SR protein-supplemented (at 0.15 $\mu \mathrm{g} / \mu \mathrm{l}$ ) extract (lanes $10-12$ ) for 5,15 , or $30 \mathrm{~min}$. Complexes $\mathrm{H}$, A, B, and C are labeled according to Konarska (1990); a distinct complex $\left(^{*}\right)$ appeared only in the $\mathrm{Ul}_{1-14}$ oligonucleotide-pretreated and SR protein-supplemented extract. The SR proteins used in this experiment were not pretreated with micrococcal nuclease because, for unknown reasons, splicing complexes (except complex C) change their mobility in native gels after exposure to EGTA-inactivated micrococcal nuclease (data not shown|. Yet, untreated SR proteins behave identically to micrococcal nuclease-treated preparations in the reconstitution of splicing, as assayed by denaturing gels.

to enhance whatever the rate-limiting step prior to catalysis might be.

\section{Discussion}

In this paper we report several novel functions of SR proteins. First, a silent $5^{\prime}$ splice site within the intron of the adenovirus pre-mRNA substrate, which is not usually thought of as an alternatively spliced RNA, can be activated by high concentrations of SR proteins. Second, excess SR proteins can compensate for at least some functions of the U1 snRNP. Third, SR proteins can activate yet another novel $5^{\prime}$ splice site within the adenovirus intron when the $5^{\prime}$ end of U1 snRNA is sequestered. These results suggest that SR proteins may contribute to more than the earliest steps of spliceosome assembly and give us new insights into the mechanism of 5 ' splice site selection and functions and evolution of the Ul snRNP.

How do SR proteins compensate for functions of the U1 snRNP?

$\mathrm{U} 1$ is the spliceosomal snRNP that was first hypothe- 
sized and confirmed to be involved in the splicing of pre-mRNA (for review, see Sharp 1994). The critical role of the $5^{\prime}$ end of U1 snRNA is recognition of the $5^{\prime}$ splice site by Watson-Crick base-pairing, leading to commitment of a pre-mRNA to the splicing pathway (Michaud and Reed 1991; for review, see Rosbash and Seraphin 1991). Here, we have employed a 2'-O-methyl oligonucleotide $\mathrm{Ul}_{1-14}$ to sequester elements near the $5^{\prime}$ end of U1 snRNA. As described by Seiwert and Steitz (1993), in addition to the 5' splice site pairing function, some other function of U1 snRNA that is essential for complex A formation is blocked (Fig. 5). Even under these conditions (as well as when only the $5^{\prime}$ end of Ul snRNA is removed), excess SR proteins can rescue splicing of premRNA substrates (Figs. 2 and 3 ).

Several results argue that in our oligonucleotide-pretreated extracts, excess SR proteins are not acting simply by reversing the block or recruiting a tiny fraction of residual U1 snRNPs. (1) Psoralen cross-linking between $\mathrm{Ul}$ and the pre-mRNA is undetectable (Fig. 4). (2) Purified recombinant $\mathrm{SC} 35$, which does not contain detectable amounts of snRNPs, can rescue splicing (Fig. 3). (3) The rescued extracts exhibit an altered 5 ' splice site preference: In addition to the normal and the +125 sites, a novel 5' splice site (site 47), not used in the presence of unblocked U1 snRNPs, is activated dominantly (Figs. 2 and 3). (4) Crispino et al. (1994) have demonstrated that extracts depleted of U1 snRNPs by affinity selection using a tethered 2'-O-methyl oligonucleotide can likewise be rescued for splicing by SR proteins. Although we cannot rule out the possibility that excess SR proteins stimulate residual U1 snRNPs to act so quickly that their interactions cannot be captured by cross-linking, the normal kinetics of splicing (data not shown) and complex assembly (Fig. 5) and the increased cross-linking of Ul snRNA in unblocked extracts (Fig. 4) argue strongly against this explanation.

The recent finding that SR proteins can directly recognize 5' splice sites (Zuo and Manley 1994) is probably key to their ability to rescue splicing in the absence of active U1 snRNPs. (It should, however, be noted that site 47 is not as purine-rich as most $5^{\prime}$ splice sites.) Whereas in normal extracts binding of the U1 snRNP is enhanced (Eperon et al. 1993), apparently other splicing factors can also be recruited to potential $5^{\prime}$ splice sites in the premRNA by SR proteins. The U6 snRNP, a splicing factor, which (like U1) can engage in $5^{\prime}$ splice site pairing (Sawa and Abelson 1992; Wassarman and Steitz 1992; KandelsLewis and Seraphin 1993; Konforti et al. 1993; Lesser and Guthrie 1993), is a likely candidate (see below).

In addition to its role in recognizing the $5^{\prime}$ splice site, the U1 snRNP assists formation of pre-splicing complex A by promoting binding of the U2 snRNP (Barabino et al. 1990), probably in collaboration with SR proteins (Fu and Maniatis 1992; W.-Y. Tarn and J. Steitz, unpubl.). Cloned SC35 behaved almost identically to mixed SR proteins in our reconstitution experiments, except that its efficiency in rescuing splicing was lower (Fig. 3). This protein has been proposed to bridge the U1 70K protein and U2AF via homodimeric or heterodimeric interactions
(Wu and Maniatis 1993). We cannot exclude the possibility that SC35 collaborates with other members of the SR protein family to achieve optimal communication between the $5^{\prime}$ and $3^{\prime}$ splice sites. Likewise, the remainder of the Ul snRNP particle may continue to participate in splicing in our U1-debilitated system. By immunoprecipitation with anti-(U1)70K antibodies (Kastner et al. 1992), we found that the $70 \mathrm{~K}$ protein was still associated with the pre-mRNA and splicing intermediates in the U1 snRNA-blocked and SR protein-supplemented extract, whereas no precipitation of RNAs was observed without excess SR proteins (W.-Y. Tarn and J. Steitz, unpubl.). To determine whether free $70 \mathrm{~K}$ protein exists in cells and extracts or the debilitated U1 snRNP provides this bridging function will require further investigation.

\section{Potential role of U6 in 5' splice site selection}

We argue above that SR proteins can bypass the normal role of the U1 snRNP by directly recruiting other splicing factors to potential $5^{\prime}$ splice sites. What then might be responsible for selecting site 47 , which is never seen to act as a $5^{\prime}$ splice site in the presence of functional U1 snRNPs? The observation that lowering the amount of extract in the reaction decreases the efficiency of splicing to site 47 (Fig. 3) suggested that some extract factor(s), rather than only components of the SR protein preparation, participates. Potential base-pairing between U6 snRNA and the three $5^{\prime}$ splice sites utilized in SR protein-supplemented and U1-blocked extracts is shown in Figure 6; interestingly, predicted pairing with site 47 is strongest. We therefore tested the hypothesis that U6 might play a determining role in selection of site 47 by mutating one nucleotide (position +52 ) of the intron to weaken the potential base-pairing interaction between U6 snRNA and site 47 . The substrate was assayed in the $\mathrm{Ul}_{1-14}$ oligonucleotide-pretreated extract following supplementation with excess amounts of SR proteins, and the efficiency of splicing to the mutated site 47 was reduced to $30 \%$ of the wild type (W.-Y. Tarn and J. Steitz, unpubl.). These results are consistent with our suspicion that $\mathrm{U} 6$ may be involved in $5^{\prime}$ splice site choice in the absence of functional U1 snRNPs. Because compensatory mutations in the U6 snRNA are not yet available, we cannot exclude alternative possibilities.

Kandels-Lewis and Seraphin (1993) and Lesser and Guthrie (1993) suggested previously that U6 snRNA provides a "proofreading function," specifying the precise bond at the 5 ' splice site for nucleophilic attack. In their genetic suppression studies in yeast, the aberrant cleavage sites activated by U6 were adjacent to an authentic $5^{\prime}$ splice site that had been mutated, implicating the participation of Ul as well. However, using a different approach, Konforti and co-workers have recently shown that an oligoribonucleotide mimicking the $5^{\prime}$ splice site can associate with snRNP complexes containing U6 when the 5' end of U1 is blocked (Konforti et al. 1993; Konforti and Konarska 1994). Although the system they used represents only a partial reaction of splicing, their result constitutes the first evidence that U6 per se can 
A

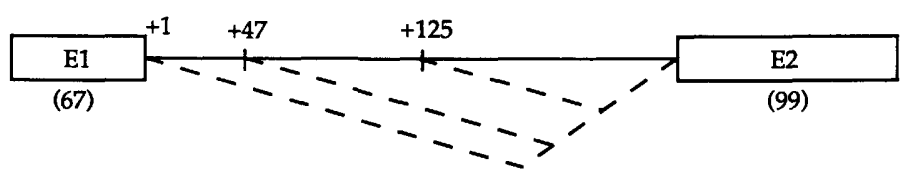

B

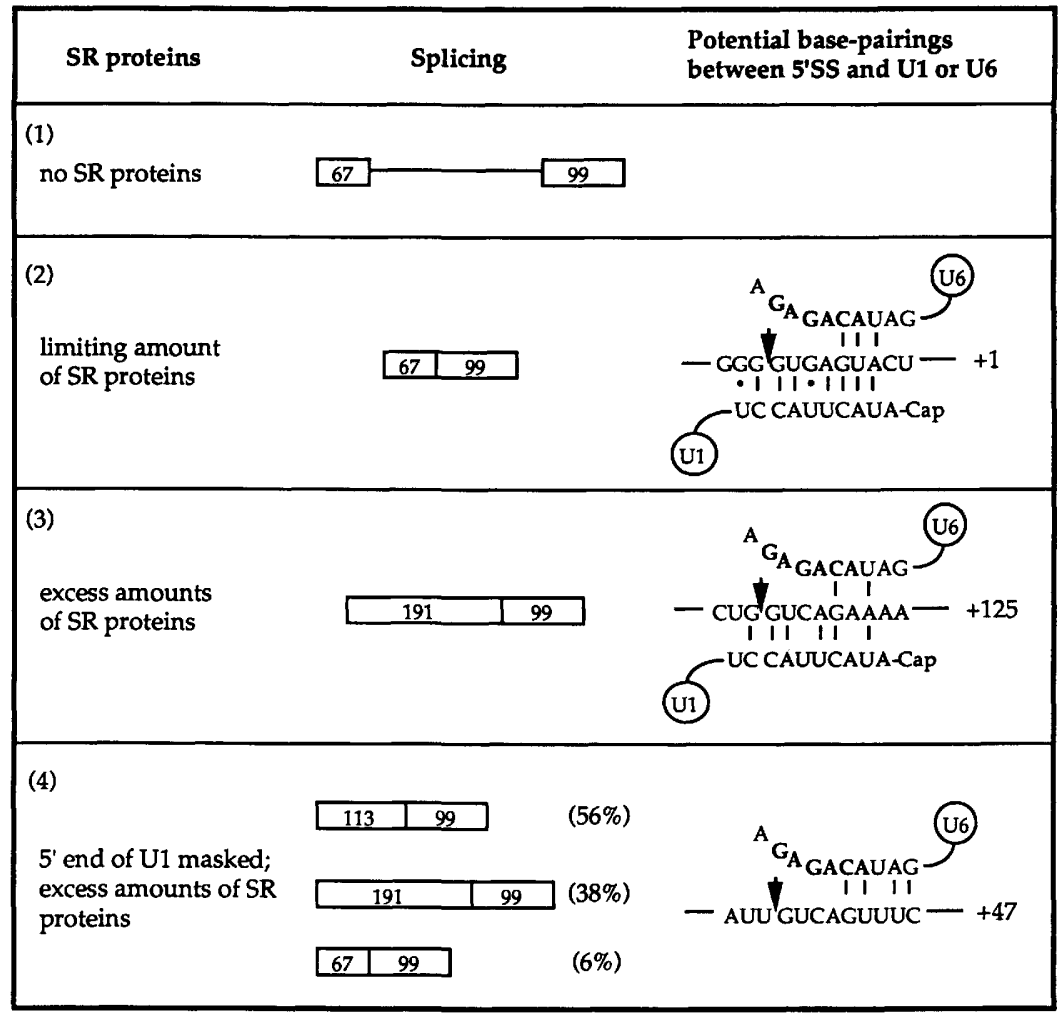

Figure 6. Alternative splicing of the adenovirus pre-mRNA substrate induced by SR proteins. $(A)$ The precursor RNA derived from the adenovirus major late transcript contains $67 \mathrm{nu}$ cleotides of exon 1 (E1), 241 nucleotides of intron, and 99 nucleotides of exon 2 (E2). The $5^{\prime}$ splice sites characterized here are +1 (the normal site), +47 , and +125 . (B) The spliced products and potential base-pairing of U1 and U6 to the various $5^{\prime}$ splice sites are shown. Limiting amount of mixed SR proteins means 1- to 2-fold the endogenous level, whereas excess amounts means $\sim 20$-fold the endogenous level. The relative splicing efficiency of site 125 and site 47 was determined by quantitating the spliced products and normalizing for the length of each band. The usage of site 125 is slightly overestimated because the spliced product comigrates with a much lower amount (5-10\%) of cognate lariat intermediate. Because the normal spliced product was barely detected in the U1-blocked extract complemented with 20 -fold SR proteins, the relative splicing efficiency of the normal site vs. site 47 was determined by quantitating the excised exons 1 and normalizing for the length of each band. Values given are the average of three independent experiments. recognize and bind a $5^{\prime}$ splice site sequence. Here, we provide a novel approach to explore further the hypothesis that $\mathrm{U} 6$ can function dominantly in the determination of the 5 ' splice site during active splicing in vitro.

Finally, an alternative possibility, that the U5 snRNP is dominant in $5^{\prime}$ splice site choice when functions of the Ul snRNP are blocked and splicing is activated by excess SR proteins, must be considered. Under normal circumstances, the U5 loop is believed to function by interacting with the terminus of the exon throughout the splicing reaction, rather than by defining the $5^{\prime}$ splice site (Wyatt et al. 1992; Sontheimer and Steitz 1993; for review, see Madhani and Guthrie 1994). When a conserved intron sequence has been mutated, Watson-Crick interactions can apparently occur between the U5 loop and the mutated pre-mRNA, allowing splicing at cryptic sites (Newman and Norman 1992; Cortes et al. 1993). In our rescue experiments, the exon sequences at the novel sites $(+47$ and +125$)$ exhibit weaker complementarity to the invariant sequence of the U5 loop than the normal site $(+1)$. Therefore, the U5 snRNP seems unlikely to be a major determinant in selection of $5^{\prime}$ splice sites in the presence of debilitated U1 snRNPs and excess SR proteins.

\section{The mechanism of $5^{\prime}$ splice site selection}

Two aspects of our results extend our understanding of how the splicing machinery discriminates among candidate $5^{\prime}$ splice sites. Previously, it was demonstrated that SR proteins favor the utilization of the proximal site in pre-mRNAs that contain alternative $5^{\prime}$ splice sites (for review, see Horowitz and Krainer 1993). Here, we have discovered that excess SR proteins can activate (Fig. 1) and recruit U1 snRNPs (Fig. 4) to a 5' splice site (site 125) that is normally silent within the intron of the adenovirus substrate. These observations suggest that as the concentration of SR proteins builds beyond its normal level, additional sites on a pre-mRNA can become occupied and the site that is most proximal is then selected for splicing. On the other hand, splicing does not necessarily follow U1 binding, as has been discussed (Reed and Maniatis 1986; Nelson and Green 1988; Eperon et al. 1993). Our psoralen cross-linking data confirm this no- 
tion by showing that SR proteins enhance binding of U1 to the normal 5' splice site (Fig. 4), even though this site is utilized very inefficiently for splicing (Fig. 2A). A. Zahler and $M$. Roth (in prep.) have also observed by cross-linking that Ul snRNPs occupy sites that are not used. More investigation is needed to understand the interactions that effectively commit a $5^{\prime}$ splice site to the splicing pathway.

Our other finding is the activation of a second silent $5^{\prime}$ splice site in the presence of excess SR proteins and debilitated U1 snRNPs. Site 47 was never potentiated by SR proteins in the presence of functional Ul snRNPs; moreover, a cross-link between the $5^{\prime}$ end of $\mathrm{Ul}$ and site 47 leven though it is pyrimidine-rich and should be an excellent cross-linker) was not observed under any conditions. These results argue that Ul plays an influential role in $5^{\prime}$ splice site utilization even at high concentrations of SR proteins. On the other hand, the use of three $5^{\prime}$ splice sites in the $\mathrm{U}_{1-14}$ oligonucleotide-pretreated extract indicates that SR proteins can circumvent the participation of $\mathrm{U} 1$ and may facilitate association of $\mathrm{U} 6$. Because increasing the concentration of SR proteins in blocked extracts increased the utilization of site 125 (the most proximal site) (Fig. 2D), we also conclude that SR proteins can promote proximal $5^{\prime}$ splice site selection, regardless of whether U1 or (presumably) U6 is functioning as the initial base-pairing partner.

\section{Functions and evolution of the U1 snRNA}

Our observations add yet another entry to a growing list of conditions under which splicing has been observed to be "U1 independent." Previously, splicing of the SV40 large $T$ intron and SL RNA-containing adenovirus constructs was shown to be less sensitive to RNase H-mediated destruction of the 5 ' end of U1 (Black and Steitz 1986; Black 1987; Bruzik and Steitz 1990), and injection of antibodies against the Ul snRNP into Xenopus oocytes did not prevent utilization of some $5^{\prime}$ splice sites (Fradin et al. 1984). Also, Eperon et al. (1993) have argued that splicing can be independent of the $5^{\prime}$ end of Ul when $5^{\prime}$ splice sites are in close proximity. These initially puzzling findings have been clarified recently by accumulating evidence that Ul serves only an early function in the spliceosome and is dispensable for subsequent catalysis (S.-L. Yean and R.-J. Lin, pers. comm.; for review, see Newman 1994). Later, U6 appears to take over and proofread the $5^{\prime}$ splice site following destabilization of U1 (Wassarman and Steitz 1992; Kandels-Lewis and Seraphin 1993; Konforti et al. 1993; Lesser and Guthrie 1993; Konforti and Konarska 1994). Our findings now suggest that U6 may cooperate with SR proteins to replace the early function of Ul in recognition of the $5^{\prime}$ splice site. Why then does the splicing of nuclear premRNAs require the Ul snRNP at all?

Spliceosomal snRNAs have been viewed as fragments of an RNA sequence that might originally have functioned as a single self-splicing molecule (for review, see Guthrie 1991; Sharp 1991) and then evolved through simpler multicomponent splicing systems. In this con- text, progress in understanding the mechanisms of both group II splicing and trans-splicing should provide insights into the functions of the spliceosomal snRNAs, including U1, in cis-splicing. For the group II intron, whose excision is mechanistically similar to the splicing of nuclear pre-mRNA, no analog to the U1-5' splice site pairing has been identified; the conserved $\epsilon-\epsilon^{\prime}$ pairing in group II introns appears instead to mimic the $5^{\prime}$ splice site-U6 interaction (for review, see Wise 1993; Newman 1994). Likewise, no U1 homolog has been identified in trypanosomatids, in which all mRNAs are believed to arise via trans-splicing (for review, see Nilsen 1992). The recent analysis of a new trans-spliceosomal U6 RNA gene (Xu et al. 1994) has revealed compensatory base changes within the conserved hexanucleotide sequence of U6 and the 5' splice sites of SL RNAs, suggesting that the $5^{\prime}$ splice site-U6 snRNA interaction is universal among splicing systems. In contrast, functions attributed to U1 snRNA appear to be dispensable for group II intron removal and for trans-splicing.

Our results suggest that Ul snRNPs may function in the first step of a double proofreading scheme in the spliceosome. Although the role of $\mathrm{Ul}$ in $5^{\prime}$ splice site recognition can be substituted by excess SR proteins and perhaps also by U6, inappropriate $5^{\prime}$ splice sites are activated. Thus, it seems that the Ul snRNP is critical for faithful selection of the correct $5^{\prime}$ splice site from many potential sites bound by SR proteins; extensive basepairing of its $5^{\prime}$ end with the true sequence is probably an important determinant (Fig. 6). After destabilization of U1 from the $5^{\prime}$ splice site, U6 proofreads the cleavage site by limited base-pairing (Fig. 6) and allows conversion of the spliceosome to a catalytically active state. We conclude that sequential recognition of the $5^{\prime}$ splice site by SR proteins, U1, and U6 is vital to the accuracy of splicing of complicated pre-mRNAs. Therefore, only in a system that has evolved the versatility to splice a multitude of structurally heterogeneous introns is $\mathrm{U} 1$ an essential splicing component.

\section{Materials and methods}

\section{Oligonucleotides}

Both deoxyoligonucleotides and 2'-O-methyl oligoribonucleotides were synthesized by John Flory at Yale University on an Applied Biosystems DNA synthesizer. The following 2'-O-methyl oligoribonucleotides were used for pretreatment of nuclear extracts: $\mathrm{Ul}_{1-14}\left(5^{\prime}\right.$-UGCCAGGUAAGUAU-3'), complementary to nucleotides 1-14 of U1 snRNA (Seiwert and Steitz 1993); $\mathrm{U} 2 \mathrm{~b}$, complementary to nucleotides $27-49$ of U2 snRNA (Lamond et al. 1989); and U73-20, complementary to nucleotides 3-20 of U7 snRNA (Scharl and Steitz 1994). Deoxyoligonucleotides used for primer extension were AdEII (5'-GGAGGCCGACGGGTTTCCGATCC-3'), complementary to nucleotides 45-67 of the $3^{\prime}$ exon, AdIa (5'-CACCCTCAAAGGCATCACCG-3' $\mid$, complementary to nucleotides 91-110 of the intron, AdIb (5'-ATCATCAAGGAAACCCTGGA-3'), complementary to nucleotides 189-208 of the intron, and the antisense $\mathrm{U} 1$ oligonucleotide, $\mathrm{Ul}_{64-75}$. Antisense deoxyoligonucleotides used for RNase $\mathrm{H}$ cleavage were $\mathrm{Ul}_{64-75}$ and $\mathrm{U}_{79-98}$. 


\section{Splicing extracts and substrates}

HeLa nuclear and S100 extracts were prepared according to Dignam et al. (1983) except that buffer D contained $50 \mathrm{~mm} \mathrm{KCl}$. Transcription reactions were carried out in $10-\mu$ l reaction mixtures containing $1 \mu \mathrm{g}$ of linearized plasmid, $20 \mu \mathrm{Ci}$ of $\left[\alpha^{-32}\right.$ P]UTP, 0.5 mM ATP and CTP, 0.1 mM GTP and UTP, $1 \mathrm{~mm}$ diguanosine triphosphate, $10 \mathrm{~mm}$ dithiothreitol, $40 \mathrm{~mm}$ Tris$\mathrm{HCl}(\mathrm{pH} 8.0), 6 \mathrm{~mm} \mathrm{MgCl}, 2 \mathrm{mM}$ spermidine, 4 units/ $\mu \mathrm{l}$ of RNase inhibitor, and $4.5 \mathrm{U} / \mu$ l of SP6 RNA polymerase (Pharmacia). For psoralen cross-linking experiments, the splicing substrate was labeled to a higher specific activity by doubling the amount of $\left[\alpha^{-}{ }^{32} \mathrm{P}\right] \mathrm{UTP}$ to $40 \mu \mathrm{Ci}$ and lowering the amount of cold UTP to $40 \mu \mathrm{M}$. All transcripts were gel purified.

\section{In vitro splicing assay and pretreatment of nuclear extracts} with 2'-O-methyl oligoribonucleotides

Splicing reactions were carried out in $10 \mu \mathrm{l}$ containing $60 \%$ nuclear extract or S100, $0.5 \mathrm{mM}$ ATP, $20 \mathrm{~mm}$ creatine phosphate, $2.4 \mathrm{~mm}$ (for nuclear extracts) or $2 \mathrm{~mm}$ (for $\$ 100$ extracts) $\mathrm{MgCl}_{2}, 1 \mathrm{U} / \mu \mathrm{l}$ of $\mathrm{RNasin}$ and $1 \times 10^{4} \mathrm{cpm}$ of radiolabeled precursor RNA $(\sim 3 \mathrm{fmoles})$ for $90 \mathrm{~min}$ at $30^{\circ} \mathrm{C}$. For $2^{\prime}-O$-methyl oligoribonucleotide-pretreated extracts, $0.1 \mathrm{~mm}$ cordycepin $\left(3^{\prime}\right.$ dATP) was included to prevent nonspecific polyadenylation of the precursor RNA. For SR protein-supplemented experiments, $2 \mu \mathrm{l}$ of SR proteins $[0.15-1.5 \mu \mathrm{g}$ ) with or without micrococcal nuclease treatment were added into a $10 \mu \mathrm{l}$ reaction mixture containing S100 extract or extract pretreated with a 2'-O-methyl oligoribonucleotide (see below). For Figure 3 only, splicing was performed in $25-\mu \mathrm{l}$ reaction mixtures containing $40 \% \mathrm{nu}-$ clear extract, $1 \mathrm{~mm}$ ATP, $20 \mathrm{~mm}$ creatine phosphate, $3 \mathrm{~mm}$ $\mathrm{MgCl}_{2}, 0.8 \mathrm{U} / \mu \mathrm{l}$ RNasin, $0.1 \mathrm{~mm}$ cordycepin, and $1 \times 10^{4} \mathrm{cpm}$ of pre-mRNA ( $\sim 3$ fmoles) for $2 \mathrm{hr}$ at $30^{\circ} \mathrm{C}$. RNA was isolated from the splicing reaction and fractionated on an $8 \%$ denaturing polyacrylamide gel. Spliced products were quantitated using a Molecular Dynamics PhosphorImager.

Pretreatment of the nuclear extract with 2'-O-methyl oligoribonucleotides was performed by incubating with $15 \mu \mathrm{M}$ $\mathrm{Ul}_{1-14}, 4 \mu \mathrm{M} \mathrm{U} 2 \mathrm{~b}$, or $10 \mu \mathrm{M} \mathrm{U} 7_{3-20}$ under splicing conditions for $10 \mathrm{~min}$ before adding the splicing substrate and SR proteins. The concentration of the $\mathrm{Ul}_{1-14}$ oligonucleotide used for inactivation of splicing is $\sim 30$-fold higher than that of the U1 snRNA.

\section{Preparation of $S R$ proteins}

Mixed SR proteins were prepared from HeLa nuclei (Cell Culture Center) according to methods described by Krainer et al. (1990a) and Zahler et al. (1992), with modifications. Frozen HeLa nuclei (from a 20-liter culture) were thawed at room temperature, washed with buffer A (Dignam et al. 1983), and centrifuged at $14,000 \mathrm{rpm}$ in an SS34 rotor for $20 \mathrm{~min}$. The nuclei were resuspended in an equal volume of buffer C [ $20 \mathrm{~mm}$ HEPES (pH 7.9), $0.42 \mathrm{M} \mathrm{NaCl}, 25 \%$ (vol/vol) glycerol, $1.5 \mathrm{mM} \mathrm{MgCl}$, $0.2 \mathrm{~mm}$ EDTA, $0.5 \mathrm{~mm}$ DTT, $0.5 \mathrm{~mm}$ PMSF] by 12 strokes of a tight pestle in a glass Dounce homogenizer. The nuclear suspension was then sonicated in four 10-sec bursts at 1-min intervals. The homogenate was nutated for $30 \mathrm{~min}$ at $4^{\circ} \mathrm{C}$ and then centrifuged at $16,500 \mathrm{rpm}$ in an SS34 rotor for $30 \mathrm{~min}$. The pellet was resuspended in an equal volume of buffer $\mathrm{C}$, except that the salt was reduced to $0.21 \mathrm{M}$. The supernatants were pooled and dialyzed for $3 \mathrm{hr}$ against buffer $\mathrm{D}$ omitting glycerol. The dialysate was centrifuged at $16,500 \mathrm{rpm}$ for $30 \mathrm{~min}$, and ammonium sulfate was added to the supernatant to $60 \%$ saturation. After 2 $\mathrm{hr}$ of stirring, the suspension was centrifuged at $17,000 \mathrm{rpm}$ for $20 \mathrm{~min}$. The supernatant was collected, and ammonium sulfate was increased to $90 \%$ saturation, stirred for $2 \mathrm{hr}$ and centrifuged as above. The $60-90 \%$ pellet was resuspended in $1.2 \mathrm{ml}$ of SR dialysis buffer (Zahler et al. 1992), dialyzed against the same buffer for $4 \mathrm{hr}$, and centrifuged at $17,000 \mathrm{rpm}$ for $20 \mathrm{~min}$ to remove insoluble materials. $\mathrm{MgCl}_{2}$ was added into the dialysate to a final concentration of $20 \mathrm{~mm}$. After $1 \mathrm{hr}$ of incubation on ice, the suspension was centrifuged at $13,000 \mathrm{~g}$ for $30 \mathrm{~min}$ in a microcentrifuge. The pellet containing SR proteins was resuspended in $160 \mu \mathrm{l}$ of buffer D containing $5 \%$ glycerol and dialyzed against the same buffer for $2 \mathrm{hr}$.

For complementation of the $\mathrm{Ul}_{1-14}$ oligonucleotide-pretreated extracts, each microgram of SR proteins was pretreated with 4 units of micrococcal nuclease (Worthington Biochem.) in the presence of $1 \mathrm{~mm} \mathrm{CaCl}$ for $10 \mathrm{~min}$ at $30^{\circ} \mathrm{C}$. Digestion was stopped by addition of $2 \mathrm{mM}$ EGTA.

\section{Psoralen cross-linking and RNase $H$ digestion}

Splicing reactions were performed as described above except that $1 \times 10^{5} \mathrm{cpm}$ of radiolabeled substrate with high specific activity was used. After incubation at $30^{\circ} \mathrm{C}$ for $10 \mathrm{~min}$, the reaction mixtures were irradiated with $365-\mathrm{nm}$ light for $10 \mathrm{~min}$ on ice in the presence of $20 \mu \mathrm{g} / \mathrm{ml}$ of AMT $\left(4^{\prime}\right.$-aminomethyl-4, $5^{\prime}, 8$ trimethyl) psoralen (HRI Associates). RNase $\mathrm{H}$ digestions of naked RNA were carried out in $10 \mu$ l containing $40 \mathrm{~mm}$ Tris- $\mathrm{HCl}$ (pH 7.5), $50 \mathrm{mM} \mathrm{KCl}, 5 \mathrm{~mm} \mathrm{MgCl}_{2}, 1 \mu \mathrm{g}$ of oligonucleotide, $2 \mu \mathrm{g}$ of carrier RNA (yeast tRNA) and 2 units of RNase $\mathrm{H}$ (Boehringer-Mannheim) for $60 \mathrm{~min}$ at $37^{\circ} \mathrm{C}$. Gel analysis of crosslinked products was as described by Wassarman and Steitz (1992); quantitation was performed on a Molecular Dynamics PhosphorImager.

\section{Primer extension}

Splicing reactions were performed as described above except that the volume of reaction was enlarged to 50-100 $\mu$ l and 0.5 $\mathrm{ng} / \mu \mathrm{l}$ of unlabeled precursor RNA substrate was included. Bands were excised from the gel, eluted, and recovered by ethanol precipitation. Primer extension was performed as described by Parker and Steitz (1987), with minor modifications.

\section{Native gels}

Splicing reactions were carried out as described above and stopped after the indicated incubation time by addition of 1 $\mathrm{mg} / \mathrm{ml}$ of heparin. Reactions were then incubated on ice for 10 min and loaded onto a $4 \%$ polyacrylamide gel (Konarska and Sharp 1987). Electrophoresis was performed at $300 \mathrm{~V}$ for $30 \mathrm{~min}$ and then at $250 \mathrm{~V}$ for $3 \mathrm{hr}$ and $30 \mathrm{~min}$.

\section{Acknowledgments}

We are most grateful to Ming Tian and Tom Maniatis (Harvard) for providing purified SC35 proteins and to R. Lührmann (Marburg) for the monoclonal antibody anti-(U1)70K. We are also indebted to John Crispino, Ben Blencowe, and Phil Sharp (Massachusetts Institute of Technology), Alan Zahler and Mark Roth (Fred Hutchinson Cancer Research Center), and S.-L. Yean and R.-J. Lin (Beckman Research Institute) for communicating unpublished data. We thank Erik Sontheimer, Christine Smith, Leo Otake, and Tim Taylor for critical reading of the manuscript and valuable discussions. Kazio Tycowski, Gil Ast, and Liz Scharl provided experimental advice and oligonucleotides. This work was supported by grant GM26514 from the National Institutes of Health.

The publication costs of this article were defrayed in part by 
payment of page charges. This article must therefore be hereby marked "advertisement" in accordance with 18 USC section 1734 solely to indicate this fact.

\section{References}

Amrein, H., M.L. Hedley, and T. Maniatis. 1994. The role of specific protein-RNA and protein-protein interactions in positive and negative control of pre-mRNA splicing by transformer 2. Cell 76: 735-746.

Barabino, S.M.L., B.J. Blencowe, U. Ryder, B.S. Sproat, and A.I. Lamond. 1990. Targeted snRNP depletion reveals an additional role for mammalian U1 snRNP in spliceosome assembly. Cell 63: 293-302.

Black, D.L. 1987. "The U2 and U4/U6 small nuclear ribonucleoproteins are required for pre-messenger RNA splicing in vitro." Ph.D. thesis, Yale University, New Haven, CT.

Black, D.L. and J.A. Steitz. 1986. Pre-mRNA splicing in vitro requires intact $\mathrm{U} 4 / \mathrm{U} 6$ small nuclear ribonucleoprotein. Cell 46: 697-704.

Bruzik, J.P. and J.A. Steitz. 1990. Spliced leader RNA sequences can substitute for the essential $5^{\prime}$ end of U1 RNA during splicing in a mammalian in vitro system. Cell 62: 889-899.

Cortes, J.J., E.J. Sontheimer, S.D. Seiwert, and J.A. Steitz. 1993. Mutations in the conserved loop of human U5 snRNA generate use of novel cryptic 5' splice sites in vivo. EMBO $\mathrm{l}$. 12: $5181-5189$.

Crispino, J.D., B.J. Blencowe, and P.A. Sharp. 1994. SR proteins complement pre-mRNA splicing reactions depleted of U1 snRNP. Science 265: 1866-1869.

Dignam, J.D., R.M., Lebovitz, and R.G. Roeder. 1983. Accurate transcription initiation by RNA polymerase II in a soluble extract from isolated mammalian nuclei. Nucleic Acids Res. 11: $1475-1489$.

Eperon, I.C., D.C. Ireland, R.A. Smith, A. Mayeda, and A.R. Krainer. 1993. Pathway for selection of $5^{\prime}$ splice sites by U1 snRNPs and SF2/ASF. EMBO I. 12: 3607-3617.

Fradin, A., R. Jove, C. Hemenway, H.D. Keiser, J.L. Manley, and C. Prives. 1984. Splicing pathways of SV40 mRNAs in X. laevis oocytes differ in their requirements for snRNPs. Cell 37: 927-936.

Fu, X.-D. 1993. Specific commitment of different pre-mRNAs to splicing by single SR proteins. Nature 365: 82-85.

Fu, X.-D. and T. Maniatis. 1992. The 35-kDa mammalian splicing factor SC35 mediates specific interactions between U1 and $\mathrm{U} 2$ small nuclear ribonucleoprotein particles at the $3^{\prime}$ splice site. 1992. Proc. Natl. Acad. Sci. 89: 1725-1729.

Fu, X.-D., A. Mayeda, T. Maniatis, and A.R. Krainer. 1992. General splicing factors SF2 and SC35 have equivalent activities in vitro, and both affect alternative $5^{\prime}$ and $3^{\prime}$ splice site selection. Proc. Natl. Acad. Sci. 89: 11224-11228.

Ge, H. and J.L. Manley. 1990. A protein factor, ASF, controls cell-specific alternative splicing of SV40 early pre-mRNA in vitro. Cell 62: 25-34.

Guthrie, C. 1991. Messenger RNA splicing in yeast: Clues to why the spliceosome is a ribonucleoprotein. Science 253: $157-163$.

Horowitz, D.S. and A.R. Krainer. 1993. Mechanisms for selecting $5^{\prime}$ splice sites in mammalian pre-mRNA splicing. Trends Genet. 10: 100-106.

Kandels-Lewis, S. and B. Seraphin. 1993. Role of U6 snRNA in 5' splice site selection. Science 262: 2035-2039.

Kastner, B., U. Kornstadt, M. Bach, and R. Luhrmann. 1992. Structure of the small nuclear RNP particle U1: Identification of the two structural protuberances with RNP-antigens
A and 70K. J. Cell Biol. 116: 839-849.

Kohtz, J.D., S.F. Jamison, C.L. Will, P. Zuo, R. Luhrmann, M.A. Garcia-Blanco, and J.L. Manley. 1994. Protein-protein interactions and 5 '-splice-site recognition in mammalian mRNA precursors. Nature 368: 119-124.

Konarska, M.M. 1990. Analysis of splicing complexes and small nuclear ribonucleoprotein particles by native gel electrophoresis. Methods Enzymol. 180: 442-453.

Konarska, M.M. and P.A. Sharp. 1987. Interactions between small nuclear ribonucleoprotein particles in formation of spliceosomes. Cell 49: 763-774.

Konforti, B.B. and M.M. Konarska. 1994. U4/U5/U6 snRNP recognizes the 5 ' splice site in the absence of U2 snRNP. Genes \& Dev. 8: 1962-1973.

Konforti, B.B., M.J. Koziolkiewicz, and M.M. Konarska. 1993. Disruption of base pairing between the $5^{\prime}$ splice site and the $5^{\prime}$ end of Ul snRNA is required for spliceosome assembly. Cell 75: 863-873.

Krainer, A.R., G.C. Conway, and D. Kozak. 1990a. Purification and characterization of pre-mRNA splicing factor SF2 from Hela cells. Genes $\Leftrightarrow$ Dev. 4: 1158-1171.

- 1990b. The essential pre-mRNA splicing factor SF2 influences $5^{\prime}$ splice site selection by activating proximal sites. Cell 62: 35-42.

Lamond, A.I., B. Sproat, U. Ryder, and J. Hamm. 1989. Probing the structure and function of U2 snRNP with antisense oligonucleotides made of 2'-O-Me RNA. Cell 58: 383-390.

Lavigueur, A., H. La Branche, A.R. Kornblihtt, and B. Chabot. 1993. A splicing enhancer in the human fibronectin alternate ED1 exon interacts with SR proteins and stimulates U2 snRNP binding. Genes \& Dev. 7: 2405-2417.

Lesser, C.F. and C. Guthrie. 1993. Mutations in U6 snRNA that alter splice site specificity: implications for the active site. Science 262: 1982-1988.

Madhani, H.D. and C. Guthrie. 1994. Dynamic RNA-RNA interactions in the spliceosome. Annu. Rev. Genet. (in press).

Manley, J. 1993. Question of commitment. Nature 365: 14.

Mayeda, A. and A.R. Krainer. 1992. Regulation of alternative pre-mRNA splicing by hnRNP A1 and splicing factor SF2. Cell 68: 365-375.

Mayeda, A., A.M. Zahler, A.R. Krainer, and M.B. Roth. 1992. Two members of a conserved family of nuclear phosphoproteins are involved in pre-mRNA splicing. Proc. Natl. Acad. Sci. 89: 1301-1304.

Michaud, S. and R. Reed. 1991. An ATP-independent complex commits pre-mRNA to the mammalian spliceosome assembly pathway. Genes \& Dev. 5: 2534-2546.

Moore, J.M., C.C. Query, and P.A. Sharp. 1993. Splicing of precursors to messenger RNAs by the spliceosome. In The RNA world (ed. R.F. Gesteland and J.F. Atkins), pp. 303-358. Cold Spring Harbor Laboratory Press, Cold Spring Harbor, New York.

Nelson, K.K. and M.R. Green. 1988. Splice site selection and ribonucleoprotein complex assembly during in vitro premRNA splicing. Genes \& Dev. 2: 319-329.

Newman, A. 1994. Activity in the spliceosome. Curr. Biology 4: 462-464.

Newman, A.J. and C. Norman. 1991. Mutations in yeast U5 snRNA alter the specificity of the 5' splice site cleavage. Cell 65: 115-124.

1992. U5 snRNA interacts with exon sequences at $5^{\prime}$ and 3' splice sites. Cell 68: 743-754.

Nilsen, T. W. 1992. Trans-splicing in protozoa and helminths. Infect. Agents Dis. 1: 212-218.

Parker, K. and J.A. Steitz. 1987. Structural studies of the human U3 ribonucleoprotein particle reveals a conserved sequence 
available for base-pairing with a pre-ribosomal RNA. Mol. Cell. Biol. 7: 2899-2913.

Piette, J.G. and J.E. Hearst. 1983. Termination sites of the in vitro nick-translation reaction on DNA that had photoreacted with psoralen. Proc. Natl. Acad. Sci. 80: 5540-5544.

Reed, R. and T. Maniatis. 1986. A role for exon sequences and splice-site proximity in splice-site selection. Cell 46: 681690.

Rosbash, M. and B. Seraphin. 1991. Who's on first? The U1. snRNP-5' splice site interaction and splicing. Trends Biochem. Sci. 16: 187-190.

Roth, M.B., A.M. Zahler, and J.A. Stolk. 1991. A conserved family of nuclear phosphoproteins localized to sites of polymerase II transcription. J. Cell. Biol. 111: 2217-2223.

Sawa, H. and J. Abelson. 1992. Evidence for a base-pairing interaction between U6 small nuclear RNA and the 5 ' splice site during the splicing reaction in yeast. Proc. Natl. Acad. Sci. 89: 11269-11273.

Scharl, E.C. and J.A. Steitz. 1994. The site of $3^{\prime}$ end formation of histone messenger RNA is a fixed distance from the downstream element recognized by the U7 snRNP. EMBO $J$. 13: $2432-2400$

Seiwert, S.D. and J.A. Steitz. 1993. Uncoupling two functions of the U1 small nuclear ribonucleoprotein particle during in vitro splicing. Mol. Cell. Biol. 13: 3135-3145.

Seraphin, B. and M. Rosbash. 1990. Exon mutations uncouple 5' splice site selection from Ul snRNA pairing. Cell 63: 619629.

Seraphin, B., L. Kretzner, and M. Rosbash. 1988. A U1 snRNA: Pre-mRNA base pairing interaction is required early in yeast spliceosome assembly but does not uniquely define the $5^{\prime}$ cleavage site. EMBO /. 7: 2533-2538.

Siliciano, P.G. and C. Guthrie. 1988. 5' splice site selection in yeast: Genetic alterations in base-pairing with U1 reveal additional requirements. Genes \& Dev. 2: 1258-1267.

Sharp, P.A. 1991. Five easy pieces. Science 254: 663.

1994. Split genes and RNA splicing. Cell 77: 805-815.

Solnick, D. 1985. Trans splicing of mRNA precursors. Cell 42: $157-164$.

Sontheimer, E.J. and J.A. Steitz. 1993. The U5 and U6 small nuclear RNAs as active site components of the spliceosome. Science 262: 1989-1996.

Sun, Q., A. Mayeda, R.K. Hampson, A.R. Krainer, and F.M. Rottman. 1993. General splicing factors SF2/ASF promote alternative splicing by binding to an exonic splicing enhancer. Genes \& Dev. 7: 2598-2608.

Tian, M. and T. Maniatis. 1993. A splicing enhancer complex controls alternative splicing of doublesex pre-mRNA. Cell 74: 105-114.

Wassarman, D.A. and J.A. Steitz. 1992. Interactions of small nuclear RNA's with precursor messenger RNA during in vitro splicing. Science 257: 1928-1925.

Wise, J.A. 1993. Guide to the heart of the spliceosome. Science 262: 1978-1979.

Wu, J.Y. and T. Maniatis. 1993. Specific interactions between proteins implicated in splice site selection and regulated alternative splicing. Cell 75: 1061-1070.

Wyatt J.R., E.J. Sontheimer, and J.A. Steitz. 1992. Site-specific cross-linking of mammalian U5 snRNP to the $5^{\prime}$ splice site before the first step of pre-mRNA splicing. Genes \& Dev. 6: 2542-2553.

Xu. G.-L., B. Wieland, and A. Bindereif. 1994. Trans-spliceosomal U6 RNAs of Crithidia fasciculata and Leptomonas seymouri: Deviation from the conserved ACAGAG sequence and potential base pairing with spliced leader RNA. Mol. Cell. Biol. 14: 4565-4570.
Yang, X., M.-R. Bani, S.-J. Lu, S. Rowan, Y. Ben-David, and B. Chabot. 1994. The $\mathrm{Al}$ and $\mathrm{Al} \mathrm{B}^{\mathrm{B}}$ proteins of heterogeneous nuclear ribonucleoparticles modulate $5^{\prime}$ splice site selection in vivo. Proc. Natl. Acad. Sci. 91: 6924-6928.

Zahler, A.M., W.S. Lane, J.A. Stolk, and M.B. Roth. 1992. SR proteins: A conserved family of pre-mRNA splicing factors. Genes \& Dev. 6: 837-847.

Zahler, A.M., K.M. Neugebauer, W.S. Lane, and M.B. Roth. 1993. Distinct functions of SR proteins in alternative premRNA splicing. Science 260: 219-222.

Zhuang, Y. and A.M. Weiner. 1986. A compensatory base change in U1 snRNA suppresses a $5^{\prime}$ splice site mutation. Cell 46: 827-835.

Zuo, P. and J.L. Manley. 1994. The human splicing factor ASF/ SF2 can specifically recognize pre-mRNA $5^{\prime}$ splice sites. Proc. Natl. Acad. Sci. 91: 3363-3367. 


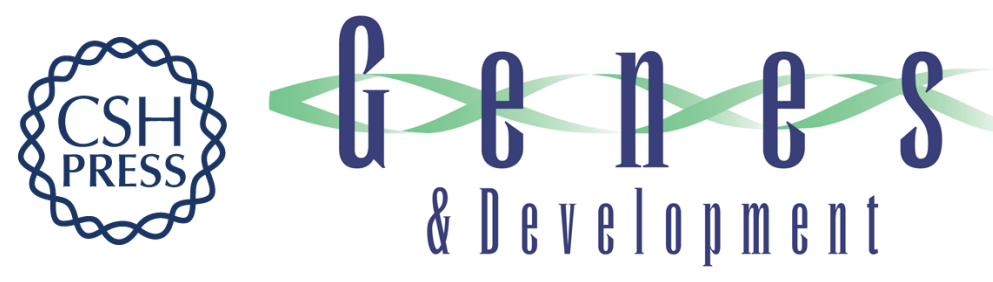

\section{SR proteins can compensate for the loss of U1 snRNP functions in vitro.}

W Y Tarn and J A Steitz

Genes Dev. 1994, 8:

Access the most recent version at doi:10.1101/gad.8.22.2704

References This article cites 63 articles, 28 of which can be accessed free at:

http://genesdev.cshlp.org/content/8/22/2704.full.html\#ref-list-1

License

Email Alerting

Service

Receive free email alerts when new articles cite this article - sign up in the box at the top right corner of the article or click here.

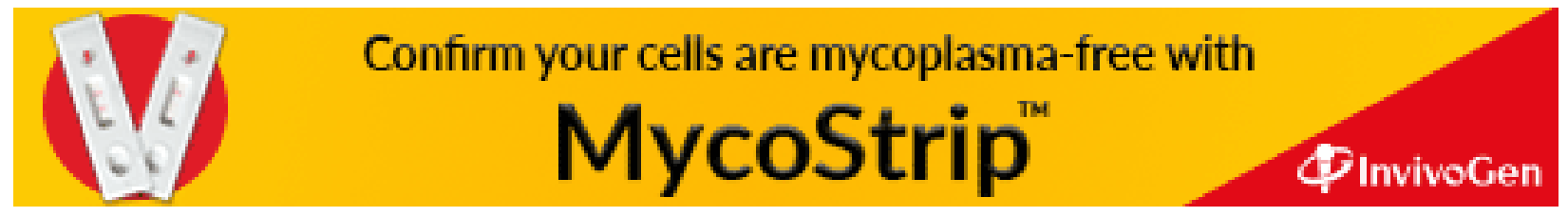

